\title{
PENGARUH MOTIVASI KERJA TERHADAP KINERJA GURU PADA SMAN 1 CANDUANG KABUPATEN AGAM
}

\author{
Nikmatul Husna \\ Universitas Putra Indonesia YPTK Padang, Indonesia \\ nikmatulhusna11@gmail.com
}

\begin{abstract}
The purpose of this research is to identify and analyze the influence of work motivation towards teachers' performances in SMAN 1 Canduang Kabupaten Agam. The population of the research is the teachers in SMAN 1 Canduang Kabupaten Agam. Samples taken are 35 respondents by using census technique, which is a technique to determine sample by selecting data from all population and using quetionnaire as data collecting tool. Based on hypotheses in this research, it is assumed that work motivation has positive and significant impact toward teachers' performance in SMA N 1 Canduang Kabupaten Agam.

The methods that author used in this research are validity test, reliability test, variable descriptive analysis, simple linear regression analysis, T test and F test. From the analysis that has been conducted, author found that the work motivation variable has positive and significant impact to teachers' performance, that has been proven by the significant probability value 0,005 which is smaller than 0.05 . Then, from the result of $F$ test, it can be concluded that the regression model can be used to predict that the work motivation has positive and significant impact on teachers' performance that is equal to 0.005 , which is much smaller than 0.05 .
\end{abstract}

Keywords : work motivatio, teachers' performance

\section{PENDAHULUAN}

Memasuki era globalisasi pada saat sekarang ini, tantangan yang dihadapi oleh Bangsa Indonesia semakin berat, khususnya dalam menghasilakn sumber daya manusia yang berkualitas dan dapat bersaing secara kompetitif. Ilmu pengetahuan dan teknologi berkembang pesat, tentu negara yang memiliki sumber daya manusia yang berkualitaslah yang dapat menguasai ilmu pengetahuan dan teknologi tersebut serta dapat memenangkan persaingan.

Dimana ketersediaan sumber daya manusia yang berkualitas serta penguasaan terhadap ilmu pengetahuan dan teknologi membutuhkan penyelenggara pendidikan yang bermutu pada setiap jenjang pendidikan. Gurulah yang berperan penting dalam hal tersebut. Guru memiliki peran yang strategis dalam bidang pendidikan, bahkan sumber daya pendidikan lain yang memadai sering kali kurang berarti apabila tidak disertai dengan kualitas guru yang memadai.

Tinggi rendahnya mutu pendidikan banyak dipengaruhi oleh bagaimana kinerja seorang guru selama proses pembelajaran. Untuk itupeningkatan kemampuan guru dalam mengelola kegiatan pembelajaran disekolah menjadi tanggungjawab kepala sekolah. Sebagaimana yang kita pahami bersama bahwa bimbingan dan pembinaan yang profesional dari kepala sekolah selalu dibutuhkan guru secara berkesinambungan. Pembinaan tersebut disamping untuk meningkatkan kinerja guru, juga diharapkan dapat memberi dampak positif terhadap munculnya sikap professional guru.

Salah satu faktor yang menjadi tolak ukur keberhasilan sekolah adalah kinerja guru dalam mengajar. Menurut Mangkunegara (2001) kinerja adalah hasil kerja secara kualitas dan kuantitas yang dicapai oleh seorang pegawai dalam melaksanakan tugasnyasesuai dengan tanggung jawab yang diberikan kepadanya. Tinggi rendahnyakinerja pekerja berkaitan erat dengan sistem pemberian penghargaan yang diterapkan oleh lembaga/organisasi tempat mereka bekerja. Pemberian penghargaan yang tidak tepat dapat berpengaruh terhadap peningkatan kinerjaseseorang. Kinerja sebagai hasil-hasil fungsi pekerjaan/kegiatan seseorang atau kelompok dalam suatu organisasi yang dipengaruhi oleh berbagai faktor untuk mencapai tujuan organisasi dalam periode waktu tertentu (Tika, 2006). Kinerja mengajar guru akan baik jika guru telah melakukan unsur-unsur yang terdiri dari kesetiaan, komitmen yang tinggi pada tugas mengajar, menguasai dan mengembangkan bahan pelajaran, kedisiplinan dalam mengajar dan tugas lainnya, kreativitas dalam pelaksanaan pengajaran, kerjasama dengan semua warga sekolah, kepemimpinan yang menjadi panutan siswa, kepribadian yang baik, jujur dan objektif dalam membimbing siswa, serta tanggung jawab terhadap tugasnya. Kinerja dikatakan baik dan memuaskan 
apabilatujuan yang dicapai sesuai dengan standar yang telah ditetapkan. Disamping itu, untuk menjamin kualitas layanan belajar mengajar atau kinerja guru yang baik, maka motivasi kerja /dorongan sangat diperlukan dalam hal ini, baik dalam bekerja maupun dalam mmberikan dorongan kepada siswanya.

Menurut Mangkunegara (2011)Motivasi merupakan dorongan yang timbul pada diri seseorang yang menggerakkan untuk melakukan sesuatu. Guru yang mempunyai motivasi kerja yang tinggi akan senantiasa bekerja keras untuk mengatasi segala jenis permasalahan yang dihadapi dengan harapan mencapai hasil yang lebih baik. Pencapaian suatu tujuan tidak lepas dari motivasi guru dalam bekerja. Motivasi merupakan pendorong semangat dan kemauan untuk bekerja dalam mencapai keberhasilan kerja. Motivasi kerja guru adalah suatu proses yang dilakukan untuk menggerakan guru agar perilaku mereka dapat diarahkan pada upaya-upaya nyata untuk mencapai tujuan yang telah ditetapkan. (Hamzah, 2011).

Berdasarkan hasil pengamatan sementara yang penulis amati, menunjukkan bahwa motivasi kerja guru pada SMAN 1 Canduang Kabupaten Agam masih tergolong redah, hal ini dapat dilihar dari masih ada beberapa orang guru yang kurang semangat dan kurang menekuni tugas yang diberikan, walaupun sudah diberikan penghargaan atau reward oleh kepala sekolah tetapi para guru tidak mengindahkannya. Mereka tetap kurang bersemangat dalam menekuni tugas yang diberikan kepadanya. Apabila motivasi kerja yang rendah ini dibiarkan terus menerus tentu akan berdampak terhadap kinerja dari seorang guru tentu akan menurun juga. Hal ini dapat dilihat dari dari jumlah pekerjaan yang dihasilkan oleh para guru dengan waktu yang telah ditentukan oleh kepala sekolah. Namun pada kenyataannya jumlah pekerjaan yang dihasilkan oleh beberapa guru pada SMAN 1 Canduang tidak sesuai dengan yang telah di intruksikan oleh kepala sekolah.

\section{LANDASAN TEORI}

\subsection{Motivasi Kerja}

\subsubsection{Pengertian Motivasi Kerja}

Menurut Malayu S.P Hasibuan (2005) motivasi adalah pemberian daya penggerak yang menciptakan kegairahan kerja seseorang agar mereka mau bekerja sama, bekerja efektif, dan terintegrasi dengan segala daya dan upayanya untuk mencapai kepuasan. Menurut Mangkunegara (2009) motivasi adalah kondisi yang menggerakkan pegawai agar mampu mencapai tujuan dari motifnya. Menurut Handoko (2003) motivasi adalah keadaan dalam pribadi seseorang yang mendorong keinginan individu untuk melakukan kegitan- kegiatan guna mencapai tujuan tertentu.

Menurut Duncan sebagaimana yang dikutip oleh Hamzah B Uno (2008), mengemukakan bahwa motivasi kerja adalah dorongan atau semangat yang timbul dari dalam diri seseorang atau pegawai untuk melakukan sesuatu atau bekerja, karena adanya rangsangan dari luar baik itu dari atasan dan lingkungan kerja, serta adanya dasar untuk memenuhi kebutuhan dan rasa puas, serta memenuhi tanggung jawab atas tugas-tugas yang diberikan dan dilakukan dalam organisasi.

Dari beberapa pendapat diatas dapat disimpulkan bahwa motivasi adalah dorongan dalam mengarahkan individu yang merangsang tingkah laku individu serta organisasi untuk melakukan tindakan guna mencapai tujuan yang telah ditetapkan.

\subsubsection{Teknik Memotivasi}

Menurut Husaini Usman (2011) teknik motiovasi terdiri dari:

a. Berfikiran positif.

Ketika mengkritik orang begitu terjadi ketidakberesan, tetapi kita lupa memberi dorongan positif agar mereka terus maju. Jangan mengkritik cara kerja orang lain kalau kita sendiri tidak mampu memberi contoh terlebih dahulu.

b. Menciptakan perubahan yang kuat.

Adanya kemauan yang kuat untuk mengubah situasi oleh diri sendiri. Mengubah perasaan tidak mampu menjadi mampu, tidak mau menjadi mau.

c. Membangun harga diri.

Banyak kelebihan kita sendiri dan orang lain yang tidak kita hargai padahal penghargaan merupakan salah satu bentuk teknik memotivasi. Berilah mereka kesempatan untuk bertanggung jawab, berilah wewenang, serta kebebasan untuk berpendapat.

d. Memantapkan pelaksanaan. 
Ungkapkan dengan jelas bagaimana cara kerja yang benar, tindakan yang dapat membantu dan menghargai seseorang dengan tulus.

e. Membangkitkan orang lemah menjadi kuat.

Buktikan bahwa mereka sudah berhasil, dan nyatakan bahwa anda akan membantu yang mereka butuhkan. Binalah keberanian, kerja keras, bersedia belajar dari orang lain.

f. Membasmi sikap menunda-nunda.

Hilangkan sikap menunda-nunda dengan alsan pekerjaan itu terlalu sulit dan segeralah untuk memulai.

\subsubsection{Teori Motivasi}

Untuk mencapai keefektivan motivasi, maka diperlukan teori-teori motivasi dari para ahli sebagai pendukungnya. Adapun teori-teori motivasi adalah sebagai berikut :

1. Teori Hirarki Kebutuhan

Teori hirarki kebutuhan merupakan teori motivasi yang paling terkenal dari Abraham Maslow. Hipotesisnya mengatakan bahwa di dalam diri semua manusia bersemayam lima jenjang kebutuhan (Maslow dalam Robbins, 2006), yaitu sebagai berikut:

a. Kebutuhan fisiologis, adalah kebutuhan manusia yang bersifat fisik.Seperti: rasa lapar, haus, perlindungan (pakaian dan perumahan), seks dan kebutuhan fisik lain.

b. Kebutuhan rasa aman, merupakan kebutuhan manusia yang munculsetelah kebutuhan fisik terpenuhi. Antara lain: keselamatan danperlindungan terhadap kerugian fisik dan emosional.

c. Kebutuhan kepemilikan sosial, ialah kebutuhan manusia yang muncul karena adanyainteraksi sosial antara manusia yang satu dengan manusia yang lainnya,dan antara manusia dengan kelompok. Mencakup: rasa kasih sayang,rasa memiliki, rasa menerima, dan persahabatan.

d. Kebutuhan penghargaan diri, yaitu kebutuhan manusia yang lebih bersifat kepentingan pribadi atau ego. Mencakup faktor penghargaan internal seperti: harga diri, otonomi, dan prestasi, serta faktor penghargaaneksternal seperti: misalnya status, pengakuan, dan perhatian.

e. Kebutuhan aktualisasi diri, adalah kebutuhanseseorang untuk menjadi manusia sesuai kecakapannya. Antara lain: pertumbuhan, pencapaian potensi, dan pemenuhan kebutuhan diri.

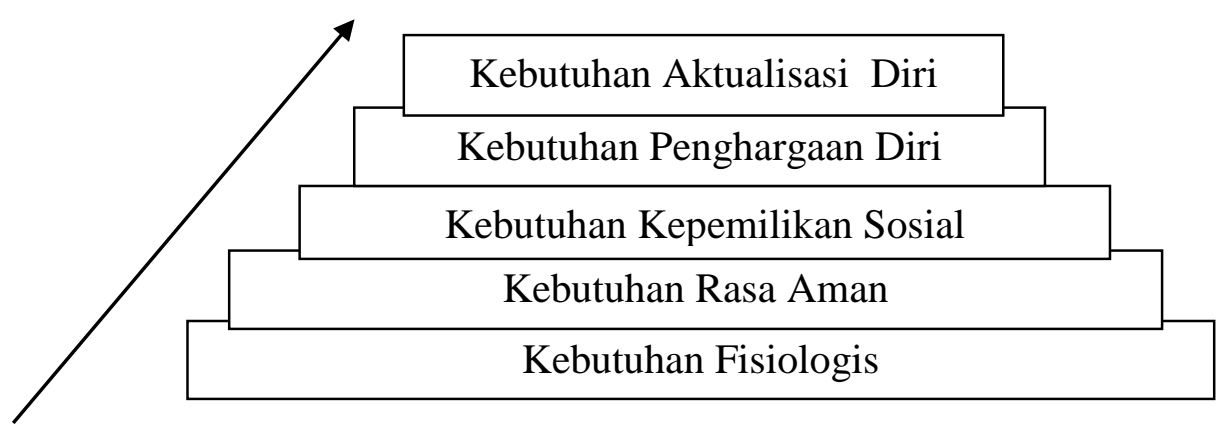

Gambar 1. Maslow's Need Hierarchy

2. Teori Keadilan

Keadilan merupakan daya penggerak yang memotivasi semangat kerja seseorang sehingga, jadi organisasi atau sekolah harus bertindak adil terhadap setiap guru. Penilaian dan pengakuan mengenai perilaku guru harus dilakukan secara obyektif. Teori ini melihat perbandingan seseorang dengan orang lain sebagai referensi berdasarkan input dan juga hasil atau kontribusi masing-masing karyawan. (Khaerul Umam, 2010 ).

3. Teori X dan Y

Teori motivasi milik Douglas Mc Gregor yang dikutip oleh Hasibuan (2007) mengemukakan dua pandangan yang nyata mengenai manusia, yakni: pandangan pertama pada dasarnya negatif disebut Teori X, dan yang lain pada dasarnya positif disebut Teori Y(Robbins, 2007).

Mc Gregor yang dikutip oleh Hasibuan (2007) menyimpulkan bahwa pandangan seorang pemimpin mengenai sifat manusia didasarkan atas beberapa kelompok asumsi tertentu, dan bahwa mereka cenderung membentuk perilaku mereka terhadap pegawai berdasarkan asumsiasumsi tersebut.Menurut Teori X, empat asumsi yang dimiliki oleh pemimpin yakni: 
a. Pegawai pada dasarnya tidak menyukai pekerjaan, dan sebisa mungkin untuk menghindarinya.

b. Karena pegawai tidak menyukai pekerjaan, mereka harus dipaksa, dikendalikan, atau diancam dengan hukuman untuk mencapai tujuan-tujuan.

c. Pegawai akan menghindari tanggung jawab dan mencari perintah formal bilamana mungkin.

d. Sebagian pegawai menempatkan keamanan di atas semua faktor lain yang terkait pekerjaan dan menunjukkan sedikit ambisi.

Kontras dengan pandangan negatif tersebut diatas, Mc Gregor membuat empat asumsi positif yang disebutnya Teori Y yaitu:

a. Pegawai menganggap kerja sebagai hal yang menyenangkan, sepertihalnya istirahat atau bermain.

b. Pegawai akan berlatih mengendalikan diri, dan emosi untuk mencapaiberbagai tujuan.

c. Pegawai akan bersedia belajar untuk menerima, bahkan belajar lebihbertanggung jawab.

d. Pegawai mampu membuat berbagai keputusan inovatif yang diedarkan keseluruh populasi, dan bukan hanya bagi mereka yang mendudukiposisi manajemen.

Kesimpulan dari teori ini yaitu Teori $\mathrm{X}$ berasumsi bahwa kebutuhan-kebutuhan tingkat yang lebih rendah mendominasi individu, sedang Teori Y berasumsi bahwa kebutuhan-kebutuhan tingkat yang lebih tinggi mendominasi individu. Mc Gregor sendiri meyakini bahwa asumsi Teori Y lebih sahih (valid) dari pada Teori X.

4. Teori motivasi dua faktor atau teori iklim sehat oleh Herzberg.

Teori ini dikemukakan oleh Herzberg berpendapat bahwa ada dua faktor ekstrinsik dan instrinsik yang mempengaruhi seseorang bekerja(Robbins,2007). Faktor ekstrinsik (hygienes) adalah hubungan interpersonal antara atasan dengan bawahan, teknik supervisi, kebijakan administratif, kondisi kerja dan kehidupan pribadi. Sedangkan faktor instrinsik (motivator) adalah faktor yang kehadirannya dapat menimbulkan kepuasaan kerja dan meningkatkan prestasi atau hasil kerja individu.

Dikutip dari Robbins, 2007 teori motivasi Herzberg (1968), faktor-faktor motivator meliputi: prestasi, pengakuan, tanggung jawab, kemajuan, pekerjaan itu sendiri dan kemungkinan berkembang.

5. Teori motivasi prestasi kerja David Mc Clelland.

Menurut Mc Clelland kebutuhan manusia yang dapat memotivasi gairah kerja dikelompokkan menjadi tiga yaitu (Robbins, 2007):

1) Kebutuhan akan prestasi, karyawan akan antusias untuk berprestasi tinggi, asalkan kemungkinan untuk hal itu diberi kesempatan, seseorang menyadari bahwa dengan hanya mencapai prestasi kerja yang tinggi akan dapat memperoleh pendapatan yang besar, dengan pendapatan yang besar ia dapat memenuhi kebutuhan- kebutuhannya.

2) Kebutuhan akan afiliasi seseorang karena kebutuhan afiliasi akan memotivasi dan mengembangkan diri serta memanfaatkan semua energinya.

3) Kebutuhan akan kekuasaan, ego manusia yang ingin berkuasa lebih dari manusia lainnya akan menimbulkan persaingan, persaingan ini oleh manajer ditumbuhkan secara sehat dalam memotivasi bawahannya supaya termotivasi untuk bekerja giat.

\subsubsection{Fungsi Motivasi}

Motivasi memiliki fungsi bagi seseorang, karena motivasi dapatmenjadikan seseorang mengalami perubahan kearah yang lebih baik.Motivasi juga dapat mendorong seseorang untuk melakukan sesuatu. Menurut Sardiman (2007) menjelaskan motivasi akan mendorong seseoranguntuk melakukan sesuatu, karena motivasi memiliki fungsi seperti:

1. Mendorong manusia untuk berbuat, jadi sebagai penggerak ataumotor yang melepaskan energi. Motivasi dalam hal ini merupakanmotor penggerak dari setiap kegiatan yang akan dikerjakan.

2. Menentukan arah perbuatan, yakni kearah tujuan yang hendakdicapai. Dengan demikian motivasi dapat memberikan arah dan kegiatan yang harus dikerjakan sesuai dengan rumusan tujuannya.

3. Menyeleksi perbuatan, yakni menentukan perbuatan-perbuatanapa yang harus dikerjakan yang serasi guna mencapai tujuan, dengan menyisihkan perbuatan-perbuatan yang tidak bermanfaatlagi bagi tujuan tersebut.

Menurut Oemar Hamalik (2004) menjelaskan fungsi motivasi antara lain: 
1. Mendorong timbulnya kelakuan atau suatu perbuatan. Perbuatan belajar akan terjadi apabila seseorang tersebut memiliki motivasi.

2. Sebagai pengarah, artinya dapat menjadi jalan agar mampu menuju arah yang ingin dicapai.

3. Sebagai penggerak, berfungsi sebagai mesin bagi mobil. Besar kecilnya motivasi akan menentukan cepat ataulambatnya suatu pekerjaan.

Berdasarkan fungsi motivasi diatas dapat disimpulkan bahwafungsi motivasi adalah memberikan arah dalam meraih apa yangdiinginkan, menentukan sikap atau tingkah laku yang akan dilakukanuntuk mendapatkan apa yang diinginkan dan juga sebagai mendorongseseorang untuk melakukan aktivitas.

\subsubsection{Faktor-Faktor Motivasi Kerja}

Motivasi merupakan faktor yang mempengaruhi semangat dan kegairahan kerja guru untuk berperan serta secara aktif dalam proses kerja. Motivasi kerja guru sangat dipengaruhi oleh faktor-faktor dari dalam maupun dari luar (Winardi 2008 ) dengan pernyataan bahwa ada tiga faktor penting yang mempengaruhi yaitu:

1. Kebutuhan-kebutuhan pribadi,

2. Tujuan - tujuan dan persepsi - presepsi orang yang bersangkutan,

3. Cara dengan apa kebutuhan-kebutuhan serta tujuan-tujuan tersebut akan direalisasikan.

Pendapat tersebut mengandung arti bahwa motivasi memuat unsur-unsur (Winardi 2008 ) :

a. Tujuan yang akan dicapai,

b. Kebutuhan yang arus dipenuhi,

c. Dorongan yang menimbulkan suatu perilaku.

Menurut Hellerigel dan Slocum (Sujak: 1990)mengklasifikasikan ada tiga faktor utama yang mempengaruhi motivasi kerja yaitu:

1. Perbedaan karakteristik individu.

2. Perbedaan karakteristik pekerjaan.

3. Perbedaan karakteristik lingkungan kerja.

Adapun menurut Nasli Syah (2003) mengemukakan bahwa sesuaidengan tugas guru dalam lapangan pendidikan ada beberapa faktor yangmempengaruhi semangat guru sebagai tenaga edukatif yaitu:

1. Faktor yang ada pada guru itu sendiri.

2. Faktor situasional.

3. Faktor kepemimpinan.

4. Faktor murid.

5. Faktor administrasi.

Herzberg (dalam Wahjosumidjo, 1994) mengemukakan bahwa kepuasan dan ketidakpuasan seseorang dalam bekerja dapat ditinjau daridua aspek, yaitu :

1. AspekIntrinsik (dapat dinilai dengan : keberhasilan, pengakuan dan pengembangan).

2. Aspek Ekstrinsik (dinilai dengan : kebijaksanaan kantor, hubungan antar personal, kepuasan akan gaji, supervisi dan kondisi kerja)

\subsection{Kinerja Guru}

\subsubsection{Pengertian Kinerja Guru}

Menurut Prawirosentono (1999) mengemukakan kinerja adalah hasil kerja yang dapat dicapai oleh seseorang atau sekelompok orang dalam suatu organisasi, sesuai dengan wewenang dan tanggung jawab masing-masing dalam rangka upaya mencapai tujuan organisasi bersangkutan secara legal, tidak melanggar hokum, dan sesuai dengan moral maupun etika. Menurut Miner (1990) kinerja adalah bagaimana seseorang diharapkan dapat berfungsi dan berperilaku sesuai dengan tugas yang telah dibebankan kepadanya. Setiap harapan mengenai bagaimana seseorang harus berperilaku dalam melaksanakan tugas, berarti menunjukkan suatu peran dalam organisasi.

Menurut Cormick dan Tiffin (2003) mengemukakan kinerja adalah kuantitas, kualitas, dan waktu yang digunakan dalam menjalankan tugas. Kuantitas adalah hasil yang dapat dihitung sejauh mana seseorang dapat berhasil mencapai tujuan yang telah ditetapkan. Kualitas adalah bagimana seseorang dalam menjalankan tugasnya, yaitu mengenai banyaknya kesalahan yang dibuat, 
kedisiplinan, dan ketepatan waktu. Waktu kerja adalah mengenai jumlah absen yang dilakukan, keterlambatan, dan lamanya masa kerja dalam tahun yang telah dijalani.

Dari definisi-definisi tersebut diatas, penulis menyimpulkan bahwa yang dimaksud dengan kinerja adalah hasil kerja yang dilihat dari aspek kualitas, kuantitas, waktu kerja dan kerja sama untuk mencapai tujuan yang sudah ditetapkan oleh organisasi.

\subsubsection{Faktor-Faktor Yang Mempengaruhi Kinerja Guru}

Menurut Anwar Prabu (2004), adapun faktor yang mendukung kinerja guru dapat digolongkan ke dalam dua macam yang penulis rangkum sebagai berikut :

a. Faktor dari dalam sendiri (intern). Di antara faktor dari dalam diri sendiri (intern) adalah :

1. Kecerdasan.

Kecerdasan memegang peranan penting dalam keberhasilan pelaksanaan tugas-tugas. Semakin rumit tugas-tugas yang diberikan makin tinggi kecerdasan yang diperlukan. Seseorang yang cerdas jika diberikan tugas yang sederhana dan monoton mungkin akan terasa jenuh dan akan berakibat pada penurunan kinerjanya.

2. Keterampilan dan kecakapan.

Keterampilan dan kecakapan orang berbeda-beda. Hal ini dikarenakan adanya perbedaan dari berbagai pengalaman, pendidikan dan latihan.

3. Bakat.

Penyesuaian antara bakat dan pilihan pekerjaan dapat menjadikan seseorang bekarja dengan pilihan dan keahliannya.

4. Kemampuan dan minat.

Syarat untuk mendapatkan ketenangan kerja bagi seseorang adalah tugas dan jabatan yang sesuai dengan kemampuannya. Kemampuan yang disertai dengan minat yang tinggi dapat menunjang pekerjaan yang telah ditekuni.

5. Motif.

Motif yang dimiliki dapat mendorong meningkatkannya kerja seseorang.

6. Kesehatan.

Kesehatan dapat membantu proses bekerja seseorang sampai selesai. Jika kesehatan terganggu maka pekerjaan terganggu pula.

7. Kepribadian.

Seseorang yang mempunyai kepribadian kuat dan integral tinggi kemungkinan tidak akan banyak mengalami kesulitan dan menyesuaikan diri dengan lingkungan kerja dan interaksi dengan rekan kerja yang akan meningkatkan kerjanya.

8. Cita-cita dan tujuan dalam bekerja.

Jika pekerjaan yang diemban seseorang sesuai dengan cita-cita, maka tujuan yang hendak dicapai dapat terlaksanakan, karena ia bekerja secara sungguh-sungguh, rajin, dan bekerja dengan sepenuh hati.

b. Faktor dari luar diri sendiri (ekstern). Yang termasuk faktor dari luar diri sendiri (ekstern) diantaranya:

1. Keadaan lingkungan keluarga dapat mempengaruhi kinerja seseorang. Ketegangan dalam kehidupan keluarga dapat menurunkan gairah kerja.

2. Lingkungan.

Situasi kerja yang menyenangkan dapat mendorong seseorang bekerja secara optimal. Tidak jarang kekecewaan dan kegagalan dialami seseorang di tempat ia bekerja. Lingkungan kerja yang dimaksud di sini adalah situasi kerja, rasa aman, gaji yang memadai, kesempatan untuk mengembangan karir.

3. Komunikasi dengan kepala sekolah.

Komunikasi yang baik di sekolah adalah komunikasi yang efektif. Tidak adanya komunikasi yang efektif dapat mengakibatkan timbulnya salah pengertian.

4. Sarana dan prasarana.

Adanya sarana dan prasarana yang memadai membantu guru dalam meningkatkan kinerjanya terutama kinerja dalam proses mengajar mengajar.

5. Kegiatan guru di kelas. 
Peningkatan dan perbaikan pendidikan harus dilakukan secara bertahap. Dinamika guru dalam pengembangan program pembelajaran tidak akan bermakna bagi perbaikan proses dan hasil belajar siswa, jika manajemen sekolahnya tidak memberi peluang tumbuh dan berkembangnya kreativitas guru. Demikian juga penambahan sumber belajar berupa perpustakaan dan laboratorium tidak akan bermakna jika manajemen sekolahnya tidak memberikan perhatian serius dalam mengoptimalkan pemanfaatan sumber belajar tersebut dalam proses belajar mengajar.

6. Kegiatan guru di sekolah.

Kegiatan guru di sekolah antara lain berpartisipasi dalam bidang administrasi, dimana dalam bidang administrasi ini para guru memiliki kesempatan yang banyak untuk ikut serta dalam kegiatan-kegiatan sekolah antara lain :

a) Mengembangkan filsafat pendidikan.

b) Memperbaiki dan menyesuaikan kurikulum.

c) Merencanakan program supervisi.

d) Merencanakan kebijakan-kebijakan kepegawaian.

Menurut Pabundu Tika (2006), faktor intern yang mempengaruhi kinerja terdiri dari kecerdasan, keterampilan, kestabilan emosi, motivasi, persepsi peran, kondisi keluarga, kondisi fisik seseorang dan karakteristik kelompok kerja, dan sebagainya. Sedangkan pengaruh eksternal antara lain berupa peraturan ketenagakerjaan, keinginan pelanggan, pesaing, nilainilai sosial, serikat buruh, kondisi ekonomi, perubahan lokasi kerja, dan kondisi pasar.

\subsubsection{Kemampuan Dasar Guru}

Depdikbud (1980) merinci 10 kemampuan dasar yang harus dimiliki guru adalah:

1. Penguasaan bahan pelajaran beserta konsep-konsep dasar keilmuan.

2. Pengelolaan proses belajar mengajar.

3. Pengelolaan kelas.

4. Penggunaan media dan sumber belajar.

5. Penguasaan landasan kependidikan.

6. Pengelolaan interaksi belajar mengajar.

7. Penilaian prestasi siswa.

8. Pengenalan fungsi program bimbingan dan penyuluhan.

9. Pengenalan dan penyelenggaraan adminidtrasi sekolah.

10. Pemahaman prinsip dan pemanfaatan hasil penelitian pendidikan untuk kepentingan peningkatan mutu pengajaran.

Nana Sujana (2000) ada empat kompetensi yang harus dimiliki oleh guru yaitu:

1. Merencanakan proses belajar mengajar.

2. Melaksanakan dan memimpin proses belajar mengajar.

3. Menilai kemajuan proses belajar mengajar.

4. Menguasai bahan pelajaran dalam arti menguasai bidabg studi yang dibinanya.

Ahmad Sanusi dkk (1991) mengemukakan karakteristik kemampuan profesional guru adalah :

1. Merencanakan proses belajar mengajar yang meliputi:

a. Merumuskan tujuan-tujuan instruksional.

b. Menguraikan deskripsi satuan bahasan.

c. Merancang kegiatan belajar mengajar.

d. Memilih media dan sumber belajar.

e. Menyusun instrumen evaluasi.

2. Melaksanakan dan memimpin proses belajar mengajar, meliputi:

a. Memimpin dan memimbing proses belajar mengajar.

b. Mengatur dan mengubah suasana belajar mengajar.

c. Menetapkan dan mengubah kegiatan belajar mengajar.

3. Menilai kemampuan belajar, yang meliputi:

a. Memberikan skor atas hasil evaluasi.

b. Mentransformasikan skor menjadi nilai.

c. Menetapkan peringkat kelas. 
d. Menafsirkan dan memanfaatkan berbagai informasi hasil penelitian dan penilaian untuk memecahkan masalah profesional pendidikan. berikut:

Surat keputusan Menpan No.84 tahun 1993 mengatur tentang tugas pokok adalah sebagai

1. Menyusun program pembelajaran.

2. Menyajikan program pembelajaran.

3. Melaksanakan evaluasi belajar.

4. Menganalisis hasil evaluasi.

5. Menyusun program perbaikan dan program pengayaan.

Selanjutnya, menurut Robbins, 1999 orang yang mempunyai kinerja yang baik mampu untuk merencanakan, melaksanakan serta menilai pekerjaannya sesuai dengan yang diharapkan. Jadi kinerja guru yang baik, jika mampu merencanakan dan melaksanakan pengajaran sesuai dengan tujuan yang hendak dicapai sehingga siswa menjadi mengerti dan memahami pengajaran yang telah diberikan guru.

\section{Penelitian Terdahulu}

Terkait penelitian tentang pengaruh disiplin kerja terhadap kinerja guru memberikan deskripsi dan kerangka konseptual yang lebih komprehensif, penelitian ini dilengkapi dengan hasil-hasil penelitian terdahulu yang sangat menunjang dan bersifat menguatkan atau melemahkan posisi bahasan topik penelitian ini.

Sebagai bahan pertimbangan dalam penelitian ini akan dicantumkan beberapa hasil penelitian terdahulu oleh beberapa peneliti yang pernah penulisbaca diantaranya:

Sukarno Andhy Yahya (2014) melakukan penelitian dimana hasil penelitiannya menunjukkan bahwa terdapat hubungan positif dan signifikan antara Gaya kepemimpinan kepala sekolah dan motivasi kerja guruterhadap kinerja guru.

Achmad Riza Fauzi (2014) melakukan penelitian dimana hasil penelitiannya menunjukkan bahwa terdapat hubungan positif dan signifikan antara kepemimpinan kepala sekolah dan motivasi kerja terhadap kinerja guru.

\section{Kerangka Pemikiran Teoritis}

Kerangka pemikiran teoritis yang dibangun dalam penelitian ini diharapkan dapat menggambarkan tentang penelitian yang akan dilakukan penulis secara keseluruhan, yaitu menguji, menganalisis dan menjelaskan pengaruh motivasi kerja terhadap kinerja guru pada SMAN 1 Canduang Kabupaten Agam. Kerangka penelitian ini menggambarkan paradigma metode penelitian secara komprehensip, yang dapat digambarkan dalam suatu kerangka proses berpikir.

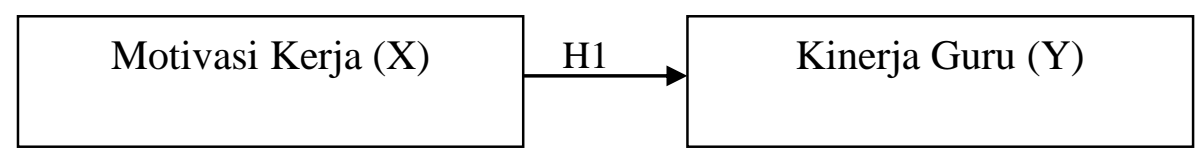

Gambar 2. Kerangka Pikir

Berdasarkan gambar kerangka pikiran di atas terlihat bahwa hubungan yang terbentuk antara variabel Y dan Xmerupakan sebuah hubungan yangsimetris yaitu dimana Y, Xsama-sama berubah dan perubahan yang terjadi pada $\mathrm{Y}$ disebabkan atau dipengaruhi oleh $\mathrm{X}$.

\section{METODOLOGI PENELITIAN}

Penilitian ini penulis lakukan pada SMAN 1 Canduang Kabupaten Agam. jenis penelitian yang dilakukan adalah penelitian deskriptif dengan menggunakan pendekatan kuantitatif yaitu mencoba untuk menggambarkan, menentukan dan menafsirkan suatu objek dalam bentuk konsep. Populasi dalam penelitian ini adalah para guru yang ada di SMAN 1 Canduang Kabupaten Agam, sedangkan sampel yang diambil sebanyak 35 responden dengan menggunakan Metode Sensus, yaitu metode penentuan sampel dengan mengambil data dari semua populasi dan menggunakan kuesioner sebagai alat pengumpul data (Singarimbun dan Effendi,2003). Teknik yang dipakai 
dalam pengumpulan data yaitu melalui riset perpustakaan, penelitian lapangan, browsing internet, metode dokumentasi dan penyebaran angket yang disebarkan kepada 35 orang responden. Definisi operasional yang dimaksud adalah untuk menjelaskan makna variabel yang sedang diteliti (Riduwan,2015), difinisi operasional yang akan dijelaskan dalam penelitian ini dilihat dari variabel independennya (X) yaitu Motivasi Kerja dengan indikator pengukuran menurut Maslow dalam Robbinns (2006) yaitu:1) kebutuhan fisiologis,2) kebutuhan rasa aman,3) kebutuhan kepemilikan sosial,4) kebutuhan penghargaan diri,5) kebutuhan aktualisasi diri sedangkan variabel dependennya adalah variabel Kinerja Guru (Y) dengan indikator pengukurannya menurut Surat Keputusan Menpan No.84 (1993) adalah 1) merencanakan program pembelajaran,2) melaksanakan pembelajaran,3) melaksanakan evaluasi program pembelajaran,4) melaksanakan tindak lanjut. Adapun metode analisis data yang penulis gunakan dalam melakukan penelitian ini adalah dengan menggunakan uji validitas dan uji reliabilitas, analisis deskriptif variable, analisis regresi linier sederhana, uji $\mathrm{T}$ dan uji $\mathrm{F}$.

\section{HASIL DAN PEMABAHASAN}

\section{Hasil Uji Validitas Dan Reliabilitas}

Dari hasil pengujian instrumen dalam penelitian ini menunjukkan bahwa seluruh item pernyataan pada variabel motivasi kerja dinyatakan valid, dan untuk item pernyataan kinerja guru juga dinyatakan valid karena koefisien korelasi dengan butir skor total lebih besar dari 0,300 (Menurut Azwar,2007). Sementara dari hasil pengujian instrumen reliabilitas variabel motivasi kerja dan variabel kinerja guru menunjukkan bahwa nilai Cronbach's Alpha untuk setiap variabel lebih besar dari 0,6, sehingga memenuhi syarat untuk pengumpulan data.

\section{Hasil Uji Deskriftif Variabel Penelitian}

Berdasarkan data yang diperoleh dari lapangan yang disesuaikan dengan fokus pernyataan penelitian, dalam bab ini akan disajikan data secara deskriptif,

a. Hasil Uji Distribusi Frekuensi Variabel Kinerja Guru

\section{Tabel 1}

Distribusi Frekuensi Variabel Kinerja guru (Y)

\begin{tabular}{|c|c|c|c|c|}
\hline No & Item Pernyataan & Rerata & TCR & Keterangan \\
\hline \multicolumn{5}{|c|}{ Merencanakan Program Pembelajaran } \\
\hline 1 & $\begin{array}{l}\text { Saya membuat program tahunan dan program } \\
\text { semester setiap awal tahun ajaran }\end{array}$ & 4,31 & 86,2 & Baik \\
\hline 2 & Saya membuat silabus sendiri & 4,20 & 84 & Baik \\
\hline 3 & $\begin{array}{l}\text { Saya merumuskan tujuan pembelajaran sesuai dengan } \\
\text { alokasi waktu yang tersedia }\end{array}$ & 4,34 & 86,8 & Baik \\
\hline 4 & Saya memilih sumber belajar yang tepat & 4,28 & 85,6 & Baik \\
\hline 5 & $\begin{array}{l}\text { Saya memilih metode yang sesuai dengan } \\
\text { karakteristik siswa }\end{array}$ & 4,25 & 85 & Baik \\
\hline \multicolumn{5}{|c|}{ Melaksanakan Pembelajaran } \\
\hline 6 & $\begin{array}{l}\text { Saya menjelaskan tujuan yang akan dicapai selama } \\
\text { kegiatan pembelajaran berlangsung }\end{array}$ & 4,37 & 87,4 & Baik \\
\hline 7 & Saya menguasai materi pembelajaran & 4,34 & 86,8 & Baik \\
\hline 8 & $\begin{array}{l}\text { Saya menggunakan metode yang bervariasi sesuai } \\
\text { dengan karakteristik siswa dan mata pelajaran }\end{array}$ & 4,42 & 88,4 & Baik \\
\hline 9 & $\begin{array}{l}\text { Saya memberikan perhatian kepada siswa yang } \\
\text { mengalami kesulitan dalam belajar }\end{array}$ & 4,37 & 87,4 & Baik \\
\hline 10 & $\begin{array}{l}\text { Saya menutup pembelajaran dengan merangkum } \\
\text { materi pelajaran }\end{array}$ & 4,40 & 88 & Baik \\
\hline \multicolumn{5}{|c|}{ Melaksanakan Evaluasi Program Pembelajaran } \\
\hline 11 & Saya membuat pedoman kriteria penilaian & 4,25 & 85 & Baik \\
\hline 12 & $\begin{array}{l}\text { Saya melakukan penilaian melalui pengamatan } \\
\text { selama proses pembelajaran berlangsung }\end{array}$ & 4,37 & 87,4 & Baik \\
\hline 13 & Saya membuat soal sesuai dengan indikator & 4,22 & 84,4 & Baik \\
\hline
\end{tabular}




\begin{tabular}{|c|c|c|c|c|}
\hline 14 & Saya melaksanakan evaluasi diakhir pembelajaran & 4,34 & 86,8 & Baik \\
\hline \multicolumn{5}{|c|}{ Melaksanakan Tindak Lanjut } \\
\hline 15 & $\begin{array}{l}\text { Saya melaksanakan tindak lanjut berdasarkan hasil } \\
\text { analisis }\end{array}$ & 4,34 & 86,8 & Baik \\
\hline 16 & $\begin{array}{l}\text { Saya mengelompokkan siswa yang mendapat } \\
\text { remedial dan pengayaan }\end{array}$ & 4,17 & 83,4 & Baik \\
\hline 17 & $\begin{array}{l}\text { Saya memberikan pengayaan kepada siswa yang } \\
\text { sudah mencapai KKM }\end{array}$ & 4,17 & 83,4 & Baik \\
\hline 18 & $\begin{array}{l}\text { Saya memberikan remedial ulang bagi siswa yang } \\
\text { masih belum mencapai KKM }\end{array}$ & 4,25 & 85 & Baik \\
\hline \multicolumn{2}{|r|}{ Rata-rata variabel } & 4,29 & $\mathbf{8 5 , 9}$ & Baik \\
\hline
\end{tabular}

Berdasarkan uraian dari Tabel diatas dapat diuraikan, bahwa skor rata-rata variabel kinerja guru adalah sebesar 4,29dengan tingkat capaian responden (TCR) sebesar 85,9\%. Hal ini menunjukkan bahwa kinerja guruPada SMAN 1 Canduang Kabupaten Agam masuk dalam kategori baik.

Dengan demikian dapat disimpulkan bahwa kinerja guruPada SMAN 1 Canduang Kabupaten Agam memiliki kategori baik dalam menjalankan aktivitasnya sehari-hari sebagai guru. Jadi, temuan penelitian ini membuktikan bahwa kinerja guru baik dalam kinerja dan tanggung jawab yang diberikan.

Dengan penilaian yang telah penulis lakukan seberapa baik kinerja guruPada SMAN 1 Canduang Kabupaten Agam maka ditemukan bahwa kinerja guru sudah masuk dalam kategori baik. Hal ini dapat dilihat dari jawaban responden terhadap indikator yang terdiri dari 18 item pernyataan, untuk itu diharapkan bagi pihak sekolah agar dapat mempertahankan kinerja guru ini atau meningkatkannya ketahap yang lebih baik lagi demi untuk kemajuan bangsa dan negara ini. Oleh karena itu perlu perbaikan terhadap kinerja guru menjadi lebih baik. Disamping itu para guru harus mampu memperbaiki cara kerja yang efektif dan efisien sesuai dengan standar yang ditetapkan dalam menyelesaikan alur pekerjaan secara tepat guna dan tepat waktu dan yang terakhir harus ada dukungan dari pimpinan / kepala sekolah.

b. Hasil Uji Distribusi Frekuensi Variabel Motivasi Kerja

Tabel 2

Distribusi Frekuensi Variabel Motivasi Kerja (X)

\begin{tabular}{|c|c|c|c|c|}
\hline No & Item Pernyataan & Rerata & TCR & Keterangan \\
\hline \multicolumn{5}{|c|}{ Kebutuhan Fisiologi } \\
\hline 1 & $\begin{array}{l}\text { Saya bekerja umumnya disebabkan oleh tuntutan } \\
\text { kebutuhan ekonomi }\end{array}$ & 4,54 & 90,8 & Sangat Baik \\
\hline 2 & $\begin{array}{l}\text { Fasilitas kerja yang disediakan oleh sekolah sangat } \\
\text { mendorong semangat kerja guru }\end{array}$ & 4,54 & 90,8 & Sangat Baik \\
\hline \multicolumn{5}{|c|}{ Rasa Aman } \\
\hline 3 & $\begin{array}{l}\text { Saya senang mendapat jaminan keamanan dan ketenangan } \\
\text { bekerja dari pimpinan saya }\end{array}$ & 4,14 & 82,8 & Baik \\
\hline \multicolumn{5}{|c|}{ Kepemilikan Sosial } \\
\hline 4 & $\begin{array}{l}\text { Saya melaksanakan tugas dengan sungguh-sungguh karena } \\
\text { kewajiban }\end{array}$ & 4,20 & 84 & Baik \\
\hline 5 & $\begin{array}{l}\text { Saya bekerja keras untuk mendapat pengakuan dari } \\
\text { masyarakat }\end{array}$ & 4,28 & 85,6 & Baik \\
\hline 6 & $\begin{array}{l}\text { Iklim berkompetensi yang sehat mendorong saya untuk } \\
\text { berprestasi }\end{array}$ & 4,37 & 87,4 & Baik \\
\hline \multicolumn{5}{|c|}{\begin{tabular}{|l} 
Penghargaan Diri \\
\end{tabular}} \\
\hline 7 & $\begin{array}{l}\text { Pemberian penghargaan akan mendorong semangat saya } \\
\text { dalam bekerja }\end{array}$ & 4,45 & 89 & Baik \\
\hline
\end{tabular}




\begin{tabular}{|c|c|c|c|c|}
\hline 8 & $\begin{array}{l}\text { Saya senang pimpinan mengajak berkomunikasi dalam } \\
\text { menyelesaikan tugas atau pekerjaan }\end{array}$ & 4,68 & 93,6 & Sangat Baik \\
\hline 9 & $\begin{array}{l}\text { Saya semangat bekerja karena pimpinan menghargai hasil } \\
\text { karya }\end{array}$ & 4,22 & 84,4 & Baik \\
\hline \multicolumn{5}{|c|}{ Aktualisasi Diri } \\
\hline 10 & $\begin{array}{l}\text { Saya berusaha keras menjadi guru yang profesional sesuai } \\
\text { ketentuan yang berlaku }\end{array}$ & 4,20 & 84 & Baik \\
\hline 11 & $\begin{array}{l}\text { Saya berusaha meningkatkan kompetensi diri melalui } \\
\text { pelatihan-pelatihan }\end{array}$ & 4,14 & 82,8 & Baik \\
\hline 12 & $\begin{array}{l}\text { Saya ingin menguasai Teknologi Informasi dan } \\
\text { Komunikasi untuk memperlancar tugas-tugas }\end{array}$ & 4,05 & 81 & Baik \\
\hline \multicolumn{2}{|r|}{ Rata-rata variabel } & 4,31 & 86,3 & Baik \\
\hline
\end{tabular}

Dari Tabel 3 diperoleh informasi bahwa skor rata-rata variabel motivasi kerja pada SMAN 1 Canduang Kabupaten Agamadalah sebesar 4,31 dengan tingkat capaian responden (TCR) sebesar $86,3 \%$. Hal ini menunjukkan bahwa motivasi kerja pada SMAN 1 Canduang Kabupaten Agammasuk dalam kategori baik. Semakin guru itu bersemangat dalam bekerja tentu hasilnya juga akan maksimal.

\section{Hasil Analisis Regresi Linier Berganda}

Tabel 3

Hasil Analisis Regresi Linier Sederhana

\begin{tabular}{|c|l|c|c|c|c|}
\hline NO & Variabel & Koefisien & t hitung & Sig & Keterangan \\
\hline & Kontanta & 53,075 & 6,506 &, 000 & \\
\hline 1 & Motivasi Kerja &, 470 & 3,006 &, 005 & H1 Diterima \\
\hline
\end{tabular}

Pada tabel tersebut menunjukkan bahwa persamaan regresi adalah sebagai berikut:

$$
\mathrm{Y}=53,075+0,470
$$

Dari persamaan tersebut dapat dijelaskan bahwa:

1. Nilai konstanta sebesar 53,075, hal ini menunjukkan bahwa sebelum dipengaruhi disiplin kerja, sebagai variabel independen, maka nilai kinerja guru adalah sebesar 53,075 dengan asumsi variabel lainya tetap.

2. Koefisien Motivasi Kerja memberikan nilai sebesar 0,470, yang berartibahwa jika motivasi kerja ditingkatkan satu satuan maka kinerja guru akan meningkat sebesar 0,470 dengan asumsi variabel lain tetap.

\section{$4 \quad$ Uji Regresi parsial (uji-t)}

1. Terdapat Pengaruh Positif Dan Signifikan Dari Variabel Motivasi Kerja Terhadap Kinerja Guru

Hasil pengolahan data dengan uji $\mathrm{t}$ diketahui bahwa nilai hasil uji $\mathrm{t}$ dari variabel motivasi kerjaadalah sebesar 3.006, nilai signifikansi dari variabel motivasi kerja adalah sebesar ,005. Jika nilai signifikansi dibandingkan dengan tingkat signifikan yang digunakan dalam penelitian ini $(\alpha=0,05)$ maka terbukti bahwa nilai signifikansi lebih kecil dari tingkat signifikan yang digunakan $(0,005<0,05)$. Hal ini berarti terdapat pengaruh positif dan signifikan dari variabel motivasi kerja terhadap kinerja guru pada SMAN 1 Canduang Kabupaten Agam. Dengan demikian hipotesis yang diajukan diterima pada tingkat kepercayaan $95 \%$.

Jadi, dapat disimpulkan bahwa semakin tinggi motivasi kerja yang diberikan maka semakin tinggi kinerja guru pada SMAN 1 Canduang Kabupaten Agam.

Hasil ini mendukung penelitian sebelumnya oleh (Sukarno Andhy Yahya, 2013dan Illa Yeni, 2012)yaitu adanya pengaruh secara positif antara motivasi kerja terhadap kinerja.

Dilihat dari hasil TCR, pada variabel independen motivasi kerja yang terdiri dari lima indikator dan dua belas item pernyataan. Yang paling tinggi nilainya adalah jawaban responden pada indiktor penghargaan diri dengan item pernyataan nomor 8 "Saya senang pimpinan mengajak berkomunikasi dalam menyelesaikan tugas atau pekerjaan". Disini 
pimpinan senang mengajak berkomunikasi sehingga terjalin hubungan yang harmonis, hubungan yang saling membutuhkan sehingga para guru juga senang dalam bekerja sedangkan jawaban responden yang paling rendah adalah pada indikator Aktualisasi diri dengan item pertanyaan nomor 12 "Saya ingin menguasai Teknologi Informasi dan Komunikasi untuk memperlancar tugas-tugas". Namun pada kenyataannnya tidak semua guru yang bisa dalam mengusai Teknologi Informasi Dan Komunikasi sehingga pekerjaannya terbengkalai, ia menjadi malas dan pada akhirnya hasil kerjanya juga menurun. Semoga untuk kedepannya kepala sekolah dapat memberikan pelatihan-pelatihan kerja berbasis teknologi informasi sehingga pekerjaan guru menjadi lancar,dan hasil kerjanya juga meningkat.

\section{$5 \quad$ Uji Regresi Simultan (Uji-f)}

Untuk menguji pengaruh variabel bebas secara bersama-sama diuji dengan menggunakan uji

F. Hasil perhitungan regresi secara bersama - sama diperlihatkan pada Tabel 4:

Tabel 4 Hasil Uji F Simultan

ANOVA $^{b}$

\begin{tabular}{|ll|c|c|c|c|c|}
\hline \multicolumn{1}{|c|}{ Model } & Sum of Squares & Df & Mean Square & F & Sig. \\
\hline 1 & Regression & 236,164 & 1 & 236,164 & 9,036 &, $005(\mathrm{a})$ \\
& Residual & 862,521 & 33 & 26,137 & & \\
Total & 1098,686 & 34 & & & \\
\hline
\end{tabular}

a. Predictors: (Constant), motivasi kerja

b. Dependent Variable: kinerja guru

Dari hasil uji signifikan $F$ didapat nilai signifikansi 0,005 dan $F$ hitung 9,036. Ini berarti bahwa model regresi dapat digunakan untuk memprediksi variabel terikat yaitu kinerja guru, karena nilai signifikansinya $<0,05$, sehingga pengujian hipotesis secara bersama - sama dapat diterima.

\section{KESIMPULAN DAN SARAN}

a. Kesimpulan

Setelah dilakukan pembahasan masalah mengenai pengaruh motivasi kerja terhadap kinerja guru pada SMAN 1 Canduang Kabupaten Agam dapat ditarik kesimpulan antara lain:

1. Motivasi kerja berpengaruh positif dan signifikan terhadap kinerja guru pada SMAN 1 Canduang Kabupaten Agam

\section{b. Saran}

Berdasarkan kesimpulan yang diperoleh dalam penelitian ini, maka penulis menyarankan :

1. Kinerja guru dilihat dari Skor TCR "saya mengelompokkan siswa yang mendapat remedial dan pengayaan masih rendah dan saya memberikan pengayaan kepada siswa yang sudah mencapai KKM masih tergolong rendah juga, maka hal ini perlu ditingkatkan dengan cara hendaknya para guru bisa memberikan, mengelompokkan, mana soal-soal yang pantas diberikan kepada siswa yang sudah mencapai KKM, dan para guru juga harus membuat standar KKM nya berapa agar 1 mata pelajaran itu dikatakan tuntas, apakah siswa ini remedial atau tidak.

2. Motivasi kerja yang di lihat dari skor TCR "Saya ingin menguasai Teknologi Informasi dan Komunikasi untuk memperlancar tugas-tugashendaknya perlu ditingkatkan. Hendaknya setiap guru diberikan pelatihan-pelatihan bagaimana menggunakan teknologi informasi dan komunikasi agar dapat mempermudah dalam melaksanakan tugas-tugas yang diberikan kepadanya. Hal ini tidak terlepas dari peran kepala sekolah untuk memberikan pelatihanpelatihan agar para guru dapat menguasai teknologi informasi sehingga pekerjaannya menjadi cepat selesai. 


\section{DAFTAR PUSTAKA}

[1] Ahmad Sanusi dkk. 1991 .Studi Pengembangan Model Pendidikan Profesional Tenaga Kependidikan. Bandung: Depdikbud IKIP

[2] A.Anwar Prabu Mangkunegara. 2004. Manajemen Sumber Daya Manusia, Remaja Rosdakarya, Bandung.

[3] A.M. Sardiman, 2007, Interaksi dan Motivasi Belajar Mengajar: Bandung, Rajawali Pers

[4] Azwar, Saifuddin. 2007. Validitas dan Reliabilitas. Yogyakarta: Pustaka Pelajar.

[5] B, Uno. Hamzah,2008.Teori Motivasi Dan Pengukurannya, Jakarta: Bumi Akasara

[6] Cornick. Mc dan Tiffin, 2003. Manajemen Kinerja. Alfabeta, Bandung.

[7] Depdikbud. 1995. Kamus Besar Bahasa Indoneia, Jakarta: Balai Pustaka

[8] Handoko, T, Hani. 2003. Manajemen, Yogjakarta : BPFE.

[9] Hamalik, Oemar. 2004. Proses Belajar Mengajar. Bumi Aksara. Jakarta.

[10] Hasibuan, Melayu S.P. 2005 .Manajemen Sumber Daya Manusia.Jakarta : Bumi Aksara

[11] Hasibuan, Malayu. 2007.Manajemen Sumber Daya Manusia, Jakarta, Bumi. Aksara.

[12] Hamzah. 2011. Teori Motivasi dan Pengukurannya.Jakarta : PT. Bumi Aksara.

[13] Mangkunegara, A. A. 2001. Manajemen Sumber Daya Manusia Perusahaan. PT. Remaja Rosdakarya, Bandung.

[14] Mangkunegara, Anwar Prabu, A.A. 2009.Manajemen Sumber Daya Manusia Perusahaan, Bandung : PT. Remaja Rosdakarya

[15] Mangkunegara, A. A. 2011. Manajemen Sumber Daya Manusia Perusahaan. PT. Remaja Rosdakarya, Bandung.

[16] Miner,John B.1990.Organizational Behaviour:Performance and Productivity,New Yrk,:Random House, Business Division

[17] Nana Sujana.2000. Dasar-dasar Proses Belajar Mengajar. Bandung: Sinar Baru Algesindo.

[18] Prawirosentono.S, 1999. Manajemen Sumber Daya Manausia, Kebijakan Kinerja Karyawan. BPFE, Yogyakarta.

[19] Robbins, Stephen. 1999. Perilaku Organisasi. Jakarta. Erlangga.

[21] Robbins, Stephen. P. 2006. Perilaku organisasi. Edisi Bahasa Indonesia. PT: Indeks Kelompok GRAMEDIA. Jakarta.

[22] Robbins, S.P, dan Judge. 2007. Perilaku Organisasi. Jakarta : Salemba Empat

[23] Skripsi. Sukarno Andhy Yahya (2013). Pengaruh Gaya Kepemimpinan Kepala Sekolah Terhadap Kinerja Guru Sd Negeri Di Kecamatan Gondokusuman Daerah Istimewa Yogyakarta

[24] Skripsi Achmad Riza Fauzi. 2014. Pengaruh Kepemimpinan Kepala Sekolah Dan Motivasi Kerja Terhadap Kinerja Guru SMP NEGERI 3 Pabelan Kab. Semarang Tahun Pelajaran 2012/2013

[25] Sujak, Abi. 1990. Kepemimpinan Manajer. Jakarta: Rajawali Pers.

[26] Surat Keputusan Menpan no.84.1993. Jabatan Fubsional Guru dan Angka Kreditnya, Jakarta

[27] Tika P. 2006. Budaya Organisasi Dan Peningkatan Kinerja Perusahaan. PT. Bumi Aksara, Jakarta

[28] Umam, Khaerul. 2010.Perilaku Organisasi,Cetakan satu, CV Pustaka Setia, Bandung.

[29] Usman, Husaini. 2011. Teori, Praktik, Dan Riset Pendidikan. Jakarta Timur: Bumi Aksara.

[30] Wajosumidjo. 1999 . Kepemimpinan Kepala Sekolah. Jakarta : Remaja Grafindo Persada

[31] Winardi. 2008. Motivasi \& permotivasian dalam manajemen.Jakarta: PT. Rajawali Press. 